\title{
Innovativeness and success perception of Polish small- and medium-sized international new ventures
}

\author{
Ewa Baranowska-Prokop \\ Institute of International Management and Marketing \\ Warsaw School of Economics \\ Poland \\ Email:ebarano@sgh.waw.pl \\ Tomasz Sikora \\ Institute of International Management and Marketing \\ Warsaw School of Economics \\ Poland \\ Email:tsikora@sgh.waw.pl
}

\begin{abstract}
The main goal of this paper is to analyse the relationship between innovativeness and success perception by managers of Polish small- and mediumsized international new ventures (INVs). We apply statistical analysis (with the use of SPSS) to the original data set elicited from the two samples of Polish SME's by means of a questionnaire and CATI technique. Two measures of success have been taken into account: assessment of financial situation and success perception of managers relative to competitors. The outcomes have been evaluated against two hypotheses. The results indicate that the propensity to innovate in Polish INVs was slightly higher in the group of medium-sized firms as compared to the small ones. The relationship between innovativeness and market success was complex. In the majority of the analysed cases the respondents from the mediumsized innovative firms evaluated success at the market in the most favourable terms whereas those from small innovative firms - in the least favourable terms.
\end{abstract} $8330.2017 / 10-3 / 10$

Received: June, 2017 1st Revision: July, 2017 Accepted: October, 2017

DOI.

Keywords: Polish international new ventures; success perception; innovativeness.

JEL Classification: L25, M13, M31

\section{INTRODUCTION AND LITERATURE REVIEW}

Undeniably, growing complexity and volatility of business environment under intense globalization processes are the main reasons for searching new efficient methods to gain competitive advantage at the global markets. International new ventures (INVs) which are on the fast internationalization track often present combination of innovative, proactive and risk-taking attitude, overstepping national boundaries and aiming at new value creation. 
The Oslo Manual (3rd edition, 2005) defines innovation as "the implementation of a new or significantly improved product (good or service), or process, a new marketing method, or a new organizational method in business practice, workplace organization, or external relations". The minimum requirement for an innovation is that the product, process, marketing method, or organizational method must be new (or significantly improved) to the firm. Innovative activities also include R\&D that is not an element of the above definition of innovations.

The problem of innovativeness of Polish enterprises is being perceived as important and complex. According to the Global Innovation Index (2016), Poland is ranked 39th, thus marking the rise in its position from 46th place in 2015. But Polish innovations are in most cases imitative in their character, and only to small extent are related to R\&D activities. Jasiński (2014) stresses that it is especially visible in Polish SME's sector. It is being reflected in relatively low number of introduced innovations and patents. GUS (2015) indicated 11 barriers to innovativeness of Polish firms. They can be divided into four groups: financial factors, knowledge issues, market factors, and others. Indisputably, financial factors and especially the lack of access to external sources of funding along with high costs of implementing innovations are more important obstacles for the SME sector than for big market players (Raport PARP, 2015).

In this paper, we analyse the innovativeness and success perception of Polish INVs. The INVs are defined as SMEs satisfying the following criteria:

- they derive at least 25 percent of their revenues from international markets within the first three years of their existence,

- the founder has a global vision of markets.

Servais and Rasmussen (2000), McDougal et al. (2003), and Coviello (2006) are stressing on constant efforts of the founders to achieve sustainable competitive advantage at international markets, but without the necessity of global presence. This is the case presented in our research.

Polish INVs were analysed by Gorynia (2007), Przybylska (2010 and 2013), Duliniec (2011), Kowalik and Baranowska-Prokop (2013), Baranowska-Prokop and Sikora (2014 and 2016), and Danik and Kowalik (2013 and 2015) in many aspects, i.e., the determinants of its formation, internationalization models, entry strategies for foreign markets, importance of psychic distance etc. This literature leads to the conclusion that the positive relationship between innovativeness and success perception of INV's managers is not obvious. Danik and Kowalik (2015) revealed that in the case of Polish born-global product quality and pricing were the main contributors to firm's success.

Baranowska-Prokop and Sikora (2016) proved there was no positive relationship between the innovativeness of Polish INVs and the success perception by their managers. In fact, there was no significant relationship between innovativeness and perceived success in neither of the two samples when all the firms (small and medium-sized) were analysed together. This finding requires more thorough analysis.

The main objective of this paper, therefore, is to find out whether firm size (small or medium) influences the relationship between innovativeness and managerial success perception.

Given the existence of innovation-supporting policies in Poland and other EU countries, the fact that managers of innovative firms did not declare higher evaluation of market success requires more indepth research.

It should be mentioned that Schumpeter's view on the role of innovation in a firm evolved over time. In his late works, he stressed that bigger companies are proportionally more innovative than the smaller ones. Also, Galbraith (1952) indicated the size of a company is an important factor for its innovative activities. Some support for this conclusion, especially for the SME's sector, could be seen also from the managerial perspective; e.g., Church and Lewis (1983) proved that in many cases at a certain stage of firm's growth the founder decides to retain status quo and not expand further. In such situations, innovations are 
rarely introduced and firm remains small in size. This is the rationale for our first hypothesis implying a positive relationship between innovativeness and firms' size.

For M. Weber and J. Schumpeter, innovativeness is a fundamental attribute determining entrepreneurship. This assumption is the basis for the second hypothesis verified in this paper concerning the positive relationship between innovativeness and success for Polish INVs.

The remainder of this paper is organized as follows. In the subsequent part, we introduce our research method and the hypotheses. Next, the discussion of our analysis results is presented. Finally, we provide the research conclusions.

\section{RESEARCH METHOD AND HYPOTHESES}

Presented research has been based on two survey studies with respondents from two representative samples of Polish international new ventures. The first was obtained in February-March $2013(\mathrm{~N}=256)$ by applying the computer assisted telephone interviews (CATI). The second was collected in SeptemberOctober 2014 ( $N=233$ ) with the use of the same method. The sampling frame was GUS data base (the "gross sample" included 19594 firms). The sample has been selected under the following conditions:

- firm was established not earlier than 1990,

- it is not an outcome of M\&A,

- it's not a branch of a foreign firm,

- it has not been privatized,

- it belongs to sector $\mathrm{C}$ - manufacturing firm (according to PKD classification),

- it started exporting during the first three years of the operations,

- it has reached at least 25 percent of revenues from exports during the first three years since the start of exporting.

Such criteria have been adopted to satisfy both this research project scope (industrial activities only) and minimum requirements concerning identification of INVs (start-ups, engaging in export activities "shortly" after being established and deriving "important" portion of their revenues from exports).

According to the market research company which collected the data, the random sampling of enterprises (within two strata: small- and medium-sized enterprises) makes it possible to apply statistical inference for the obtained results.

The analysis has been focused on the manufacturing firms.

As mentioned above, we analyze the impact of the firm size (small or medium) on the innovativeness and on the relationship between innovativeness and managerial success perception. We formulate the following two main hypotheses:

H1: there is a positive relationship between the INV's size and its innovativeness,

H2: there is a positive relationship between innovativeness of small- and medium-sized INVs and their market success (as declared by their managers).

The success has been measured by its managerial perception. For that purpose, the following two questions (with answers measured on 5-point Likert scale) have been included in the questionnaire:

1) "Considering the financial indices (e.g. profitability) for our firm, it can be concluded that our company has been successful", and

2) "Considering the situation on the (domestic and foreign) markets, where our firm operates, it can be concluded that our company has been successful in comparison to its competitors".

This success-evaluation method is the solution to the fact that the detailed financial data of unlisted enterprises are not published. 


\section{RESEARCH RESULTS}

Table 1 shows the percentage of innovative and non-innovative enterprises in the first sample of INVs when the small and medium-sized enterprises are analyzed separately.

Table 1

Numbers and percentages of innovative and non-innovative enterprises (first sample)

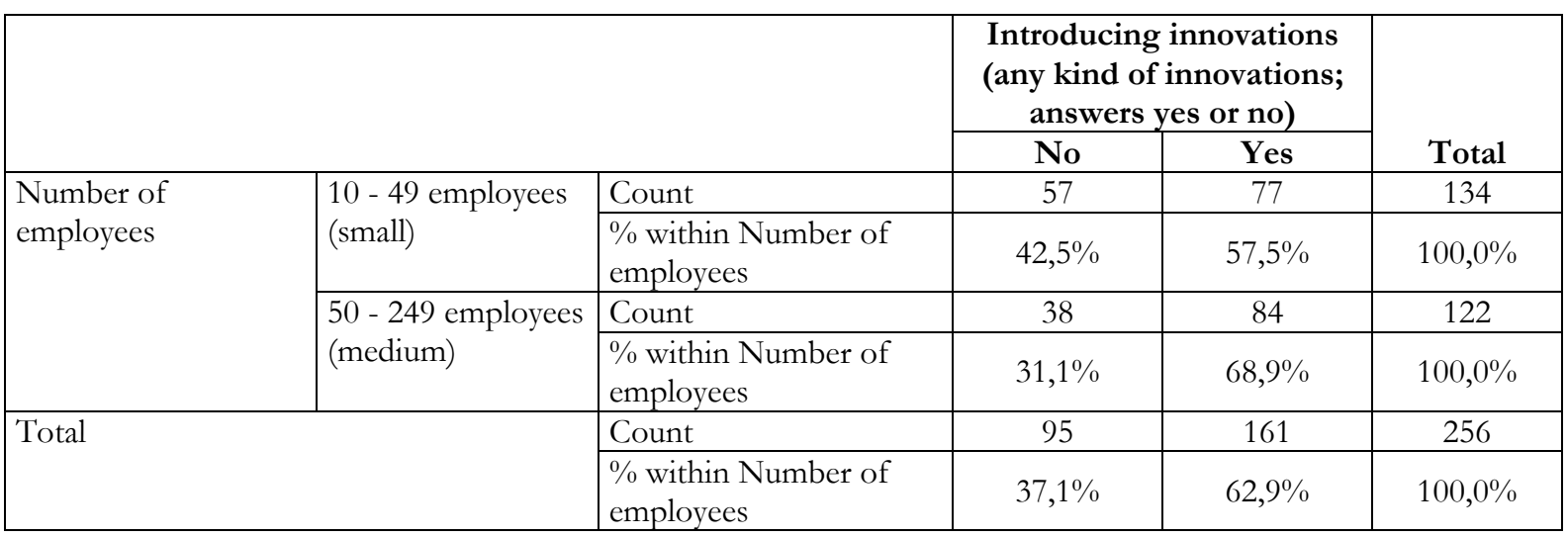

Source: own calculations, $\mathrm{N}=256$

Medium-sized enterprises are marginally more innovative than the small ones $\left(\chi^{2}=3,55, \mathrm{p}=0,06\right)$. We may consider that the hypothesis $\mathrm{H} 1$ has been confirmed for this sample.

The results of the analysis of variance concerning the relationship between the first measure of the success perception (overall financial success), the size of enterprises and their innovativeness for the first sample is shown in table 2.

Table 2

Tests of between-subjects' effects concerning the relationship between the success perceptions by managers and the size of enterprises and their innovativeness (first sample)

Dependent Variable: Overall financial success perceptions

\begin{tabular}{|l|c|c|c|c|c|}
\hline \multicolumn{1}{|c|}{ Source } & $\begin{array}{c}\text { Type III Sum of } \\
\text { Squares }\end{array}$ & df & Mean Square & F & Sig. \\
\hline Corrected Model & $9,042^{\mathrm{a}}$ & 3 & 3,014 & 3,732 &, 012 \\
\hline Intercept & 3872,546 & 1 & 3872,546 & 4795,513 &, 000 \\
\hline employees & 1,194 & 1 & 1,194 & 1,479 &, 225 \\
\hline innovations &, 042 & 1 &, 042 &, 052 &, 819 \\
\hline employees * innovations & $\mathbf{5 , 6 8 6}$ & $\mathbf{1}$ & $\mathbf{5 , 6 8 6}$ & $\mathbf{7 , 0 4 2}$ & $\mathbf{, 0 0 8}$ \\
\hline Error & 201,076 & 249 &, 808 & & \\
\hline Total & 4477,000 & 253 & & & \\
\hline Corrected Total & 210,119 & 252 & & & \\
\hline a. R Squared =,043 (Adjusted R Squared =,032)
\end{tabular}

Source: own calculations, $\mathrm{N}=256$.

It appears that both main effects are not significant, but there exists a significant interaction (shown in Figure 1). 


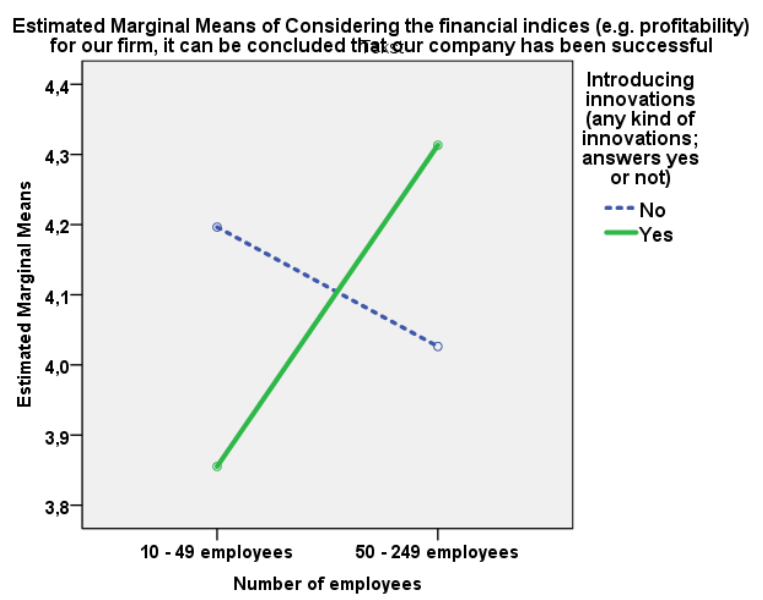

Figure 1. Interaction between firms' size, innovativeness and overall financial success (first measure of success, first sample)

Source: own calculations, $\mathrm{N}=256$

This interaction shows that for the small enterprises the hypothesis $\mathrm{H} 2$ is not confirmed. Although managers from the non-innovative firms evaluated their success better than those from the innovative ones, this difference is not significant.

The difference between innovative and non-innovative medium-sized enterprises was also not significant. Finally, innovativeness in medium-sized enterprises led to better evaluation of the financial success than innovativeness in the small enterprises. It should be stressed, however, that the value of 3 was a midpoint of the scales measuring the success (with the value range from 1 to 5) and all means above that value are in the "success zone".

For the second measure of success (success compared to competitors) in the first sample, neither the main effects nor interaction were significant (at the threshold of $\mathrm{p}=0,1$ ). The pattern of means is shown in Figure 2.

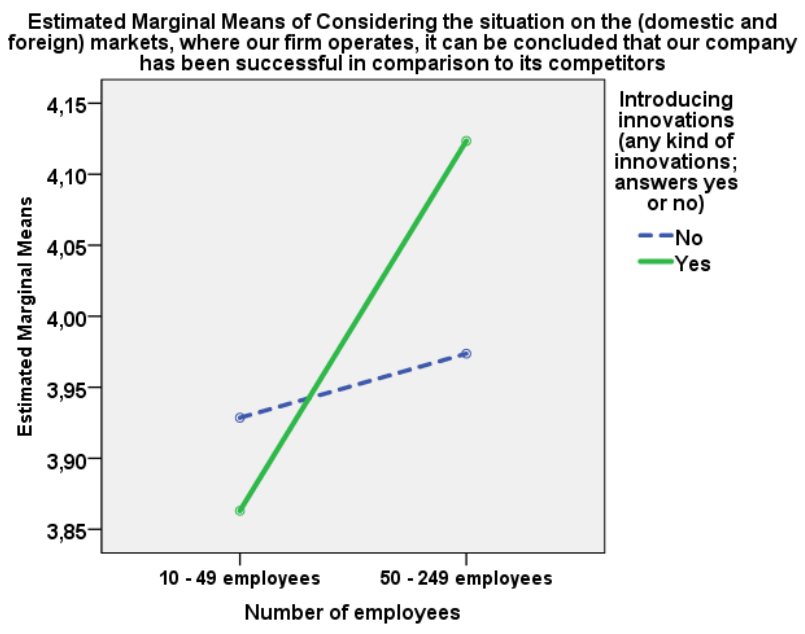

Figure 2. The pattern of means for firms' size, innovativeness and success compared to competitors (second measure of success, first sample).

Source: own calculations, $\mathrm{N}=256$ 
Small innovative firms and the medium-sized ones are also the "extreme" cases. Despite insignificant differences, the figure has been presented, because the pattern of numerical differences is similar to the evaluation of the first measure of success.

The percentages of innovative and non-innovative firms from the second sample are shown in the table 3 .

Table 3

Numbers and percentages of innovative and non-innovative enterprises (second sample)

\begin{tabular}{|c|c|c|c|c|c|}
\hline & \multicolumn{2}{|c|}{$\begin{array}{l}\text { Introducing innovations } \\
\text { (any kind of innovations; } \\
\text { answers yes or no) }\end{array}$} & \multirow[b]{2}{*}{ Total } \\
\hline & & & No & Yes & \\
\hline \multirow{4}{*}{$\begin{array}{l}\text { Number of } \\
\text { employees }\end{array}$} & \multirow{2}{*}{$\begin{array}{l}10-49 \text { employees } \\
\text { (small) }\end{array}$} & Count & 47 & 84 & 131 \\
\hline & & $\begin{array}{l}\% \text { within Number of } \\
\text { employees }\end{array}$ & $35,9 \%$ & $64,1 \%$ & $100,0 \%$ \\
\hline & \multirow{2}{*}{$\begin{array}{l}50 \text { - } 249 \text { employees } \\
\text { (medium) }\end{array}$} & Count & 29 & 73 & 102 \\
\hline & & $\begin{array}{l}\% \text { within Number of } \\
\text { employees }\end{array}$ & $28,4 \%$ & $71,6 \%$ & $100,0 \%$ \\
\hline \multirow{2}{*}{\multicolumn{2}{|c|}{ Total }} & Count & 76 & 157 & 233 \\
\hline & & $\begin{array}{l}\% \text { within Number of } \\
\text { employees }\end{array}$ & $32,6 \%$ & $67,4 \%$ & $100,0 \%$ \\
\hline
\end{tabular}

Source: own research, $\mathrm{N}=233$

Although, as in the case of the first sample, numerically (expressed in percentages), the small enterprises show less propensity to innovate than the medium-sized ones, the difference is not significant $\left(\chi^{2}=1,447\right.$, $\mathrm{p}=0,261)$. Therefore, the hypothesis H1 is not confirmed for this sample.

The results of the analysis of variance concerning the relationship between the first measure of the success perception (overall financial success), the size of enterprises and their innovativeness, for the second sample will not be shown, because no significant differences have been found.

The pattern of means is shown in the figure 3.

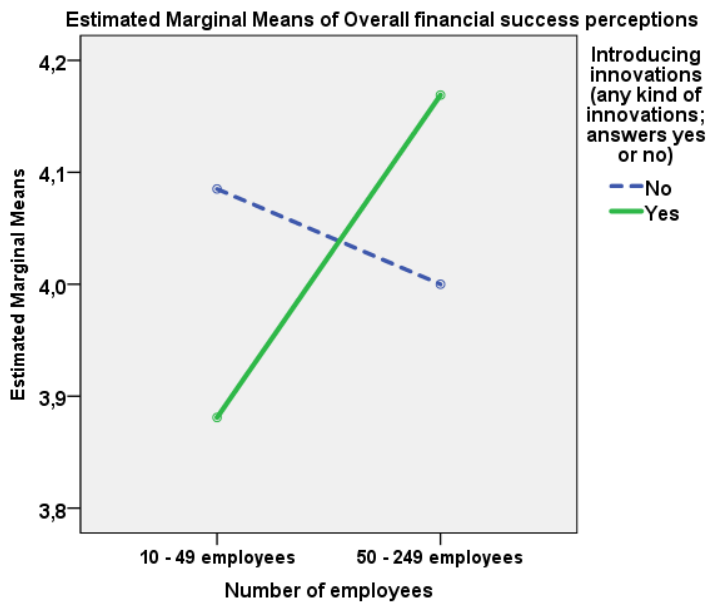

Figure 3. The pattern of means for firm size, innovativeness and overall financial success (second sample).

Source: own research, $\mathrm{N}=233$ 
Despite nonsignificant differences, the pattern of means is shown because it is similar to the analogous relationship in the first sample also for the first measure of success (figure 1). Since the relationship is not significant it cannot lead to general conclusions.

The results of the analysis of variance concerning the relationship between the second measure of the success perception (success compared to competitors), the size of enterprises and their innovativeness for the second sample is shown in the table 4 .

Table 4

Tests of between-subjects' effects concerning the relationship between the success perceptions by managers and the size of enterprises and their innovativeness (second sample)

Dependent Variable: Success compared to competitors

\begin{tabular}{|l|c|c|c|c|c|}
\hline \multicolumn{1}{|c|}{ Source } & $\begin{array}{c}\text { Type III Sum of } \\
\text { Squares }\end{array}$ & df & Mean Square & F & Sig. \\
\hline Corrected Model & $7,144^{a}$ & 3 & 2,381 & 3,100 &, 028 \\
\hline Intercept & 3154,229 & 1 & 3154,229 & 4106,163 &, 000 \\
\hline employees & $\mathbf{2 , 4 4 5}$ & $\mathbf{1}$ & $\mathbf{2 , 4 4 5}$ & $\mathbf{3 , 1 8 3}$ & $\mathbf{, 0 7 6}$ \\
\hline innovations & 1,722 & 1 & 1,722 & 2,242 &, 136 \\
\hline employees * innovations &, 965 & 1 &, 965 & 1,257 &, 263 \\
\hline Error & 172,838 & 225 &, 768 & & \\
\hline Total & 3828,000 & 229 & & & \\
\hline Corrected Total & 179,983 & 228 & & & \\
\hline
\end{tabular}

a. $\mathrm{R}$ Squared $=, 040$ (Adjusted R Squared $=, 027$ )

Source: own calculations, $\mathrm{N}=233$

As distinct from the previous three cases, the main effect of enterprise size (employees) is marginally significant.

The means of answers reveal that, in general, non-innovative enterprises evaluated their success better than the innovative ones. The pattern of means is shown in figure 4.

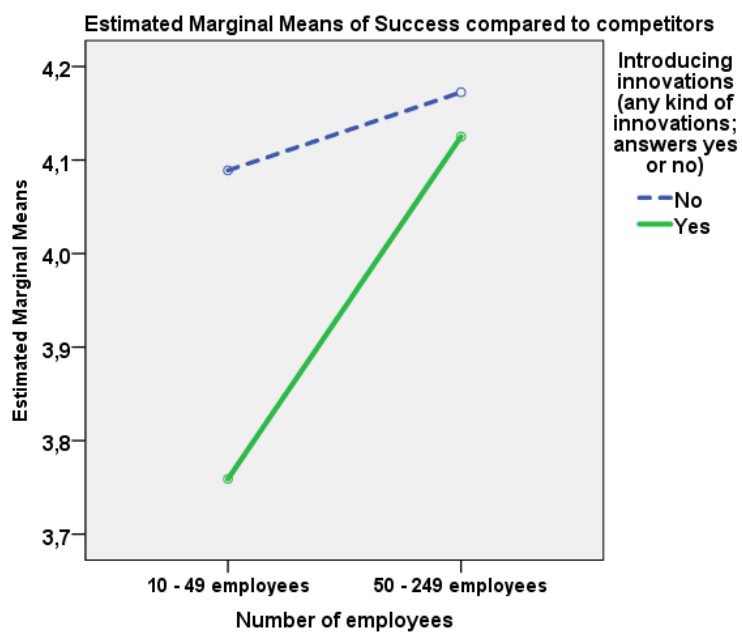

Figure 4. The pattern of means for firms' size, innovativeness and success compared to competitors (the second sample)

Source: own calculations, $\mathrm{N}=233$ 
The difference is not significant for the medium-sized enterprises, but it is significant for small ones. Managers from non-innovative firms were more satisfied with the results of competition on the market than those from the innovative ones. We may conclude that hypothesis H2 is not confirmed (no relationship) for the medium-sized enterprises, however, the results for the small enterprises suggest the opposite - a negative relationship.

Specific forms of innovations concerning marketing-mix tools (asked about independently of the previously analyzed innovations): innovations in distribution and innovations in promotion have been analyzed among firms from the second sample only. Questions about marketing innovations have been asked separately, because - as indicated results from open-ended questions from the first sample respondents spontaneously declared negligible number of marketing innovations other than new products.

The percentages of innovative and non-innovative firms from the second sample are shown in the table 5 .

Table 5

Numbers and percentages of innovative and non-innovative enterprises in the domain of distribution (second sample)

\begin{tabular}{|c|c|c|c|c|c|}
\hline & & & $\begin{array}{r}\text { Inno } \\
\text { dis }\end{array}$ & is in & \\
\hline & & & No & Yes & Total \\
\hline Number of employees & 10 - 49 employees & Count & 119 & 12 & 131 \\
\hline & & $\begin{array}{l}\% \text { within Number of } \\
\text { employees }\end{array}$ & $90,8 \%$ & $9,2 \%$ & $100,0 \%$ \\
\hline & 50 - 249 employees & Count & 84 & 18 & 102 \\
\hline & & $\begin{array}{l}\% \text { within Number of } \\
\text { employees }\end{array}$ & $82,4 \%$ & $17,6 \%$ & $100,0 \%$ \\
\hline Total & & Count & 203 & 30 & 233 \\
\hline & & $\begin{array}{l}\% \text { within Number of } \\
\text { employees }\end{array}$ & $87,1 \%$ & $12,9 \%$ & $100,0 \%$ \\
\hline
\end{tabular}

Source: own calculations, $\mathrm{N}=233$

Medium-sized enterprises have been slightly more innovative than the smaller ones in the domain of distribution $\left(\chi^{2}=3,682, \mathrm{p}=0,055\right)$. We may consider that the hypothesis $\mathrm{H} 1$ has been confirmed for this form of innovations in the second sample.

Since, as it has been indicated above, only a small minority - 30 enterprises out of $233(12.9 \%$, see table 5) declared introducing innovations in distribution and secondly, no significant relationships have been found between success perceptions, firms size and innovativeness, the detailed results concerning innovations in distribution will not be discussed.

The propensity to innovate was substantially higher in the domain of promotion, because 101 firms out of 233 declared being innovative (43,3\%, see table 6$)$.

The percentages of innovative and non-innovative firms in the domain of promotion from the second sample are shown in the table 6.

Although numerically (expressed in percentages), the medium-sized enterprises show more propensity to innovate than the small ones, the difference is not significant $\left(\chi^{2}=0,551, \mathrm{p}=0,458\right)$. Therefore, the hypothesis $\mathrm{H} 1$ is not confirmed for this form of innovations. 
Table 6

Numbers and percentages of innovative and non-innovative enterprises in the domain of promotion (second sample)

\begin{tabular}{|c|c|c|c|c|c|}
\hline & \multicolumn{2}{|c|}{$\begin{array}{c}\text { Innovations in } \\
\text { promotion }\end{array}$} & \multirow[b]{2}{*}{ Total } \\
\hline & & & No & Yes & \\
\hline \multirow[t]{4}{*}{ Number of employees } & \multirow[t]{2}{*}{10 - 49 employees } & Count & 77 & 54 & 131 \\
\hline & & $\begin{array}{l}\% \text { within Number of } \\
\text { employees }\end{array}$ & $58,8 \%$ & $41,2 \%$ & $100,0 \%$ \\
\hline & \multirow[t]{2}{*}{50 - 249 employees } & Count & 55 & 47 & 102 \\
\hline & & $\begin{array}{l}\text { \% within Number of } \\
\text { employees }\end{array}$ & $53,9 \%$ & $46,1 \%$ & $100,0 \%$ \\
\hline \multirow{2}{*}{\multicolumn{2}{|c|}{ Total }} & Count & 132 & 101 & 233 \\
\hline & & $\begin{array}{l}\% \text { within Number of } \\
\text { employees }\end{array}$ & $56,7 \%$ & $43,3 \%$ & $100,0 \%$ \\
\hline
\end{tabular}

Source: own calculations, $\mathrm{N}=233$

The results of the analysis of variance concerning the relationships between the first measure of the success perception (overall financial success), the size of enterprises and their innovativeness in the domain of promotion, for the second sample, is shown in the table 7 .

Table 7

Tests of between-subjects' effects concerning the relationship between the success perceptions by managers and the size of enterprises and their innovativeness in the domain of promotion (second sample)

Dependent Variable: Overall financial success perceptions

\begin{tabular}{|l|c|c|c|c|c|}
\hline \multicolumn{1}{|c|}{ Source } & $\begin{array}{c}\text { Type III Sum of } \\
\text { Squares }\end{array}$ & df & Mean Square & F & Sig. \\
\hline Corrected Model & $4,054^{a}$ & 3 & 1,351 & 1,669 &, 174 \\
\hline Intercept & 3629,059 & 1 & 3629,059 & 4482,275 &, 000 \\
\hline employees & 2,022 & 1 & 2,022 & 2,497 &, 115 \\
\hline innovpromotion &, 001 & 1 &, 001 &, 002 &, 968 \\
\hline employees * innovpromotion & $\mathbf{2 , 4 7 1}$ & $\mathbf{1}$ & $\mathbf{2 , 4 7 1}$ & $\mathbf{3 , 0 5 2}$ & $\mathbf{0 8 2}$ \\
\hline Error & 183,790 & 227 &, 810 & & \\
\hline Total & 3932,000 & 231 & & & \\
\hline Corrected Total & 187,844 & 230 & & & \\
\hline
\end{tabular}

a. R Squared $=, 022$ (Adjusted R Squared $=, 009)$

Source: own calculations, $\mathrm{N}=233$

Results are similar to the first analyzed case (table 2) with the two main effects being insignificant and with a marginally significant interaction.

The interaction pattern is shown in the figure 5 . 


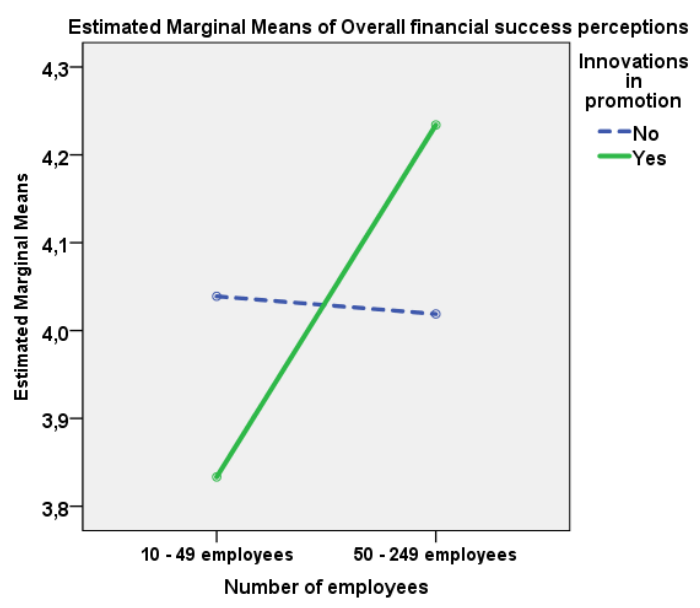

Figure 5. Interaction between firms' size, innovativeness in the domain of promotion and overall financial success (second sample)

Source: own calculations, $\mathrm{N}=233$

Although there is virtually no difference between the non-innovative firms, the extreme cases are the innovative ones: the small firms evaluated their success less favorably than the medium-sized ones.

The results of the analysis of variance concerning the relationship between the second measure of the success (success compared to competitors), the size of enterprises and their innovativeness in the domain of promotion, for the second sample, are shown in the table 8 .

Tests of between-subjects' effects concerning the relationship between the success perceptions by managers and the size of enterprises and their innovativeness in the domain of promotion

(second sample)

Dependent Variable: Success compared to competitors

\begin{tabular}{|l|c|c|c|c|c|}
\hline \multicolumn{1}{|c|}{ Source } & $\begin{array}{c}\text { Type III Sum of } \\
\text { Squares }\end{array}$ & df & Mean Square & F & Sig. \\
\hline Corrected Model & $6,534^{a}$ & 3 & 2,178 & 2,825 &, 040 \\
\hline Intercept & 3590,944 & 1 & 3590,944 & 4658,220 &, 000 \\
\hline employees & $\mathbf{3 , 5 5 2}$ & $\mathbf{1}$ & $\mathbf{3 , 5 5 2}$ & $\mathbf{4 , 6 0 8}$ & $\mathbf{, 0 3 3}$ \\
\hline innovpromotion & $\mathbf{2 , 5 8 8}$ & $\mathbf{1}$ & $\mathbf{2 , 5 8 8}$ & $\mathbf{3 , 3 5 7}$ & $\mathbf{, 0 6 8}$ \\
\hline employees * innovpromotion &, 000 & 1 &, 000 &, 000 &, 983 \\
\hline Error & 173,449 & 225 &, 771 & & \\
\hline Total & 3828,000 & 229 & & & \\
\hline Corrected Total & 179,983 & 228 & & & \\
\hline
\end{tabular}

a. R Squared $=, 036$ (Adjusted R Squared $=, 023)$

Source: own calculations, $\mathrm{N}=233$

In this case the situation is different from the previous cases. Both main effects are either significant (size) or marginally significant (innovation in promotion), while the interaction between them is not. All means are shown in the figure 6. 


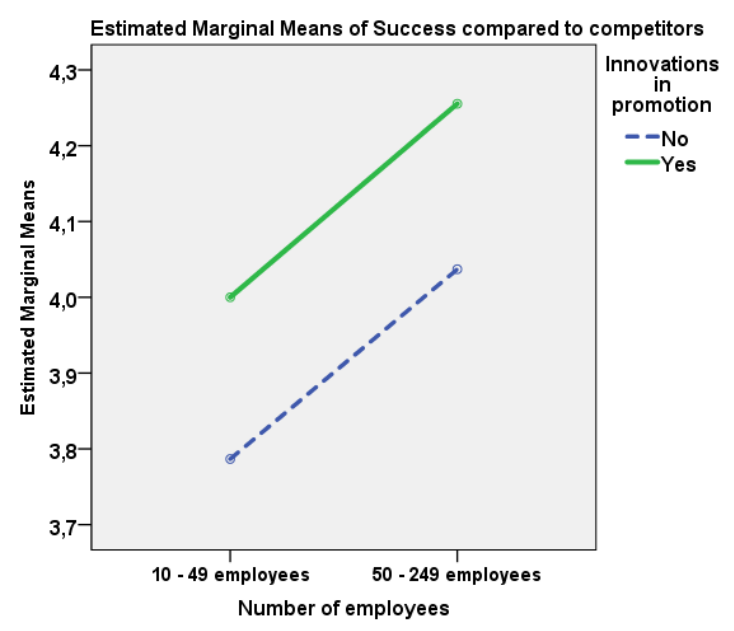

Figure 6. Effects of firms' size and innovativeness in the domain of promotion on the perceived success compared to competitors (second sample)

Source: own calculations, $\mathrm{N}=233$

Larger firms gave better (or higher) evaluations of their success than the smaller ones and the same applied to the innovative ones, which evaluated their success in more favorable terms than the noninnovative firms. The case of innovations in promotion is the single one in the above-presented analyses, where innovative small companies evaluated their success better than the non-innovative ones (and where H2 was confirmed).

\section{DISCUSSION}

The presented analysis leads to the following observations:

- referring to answers to two questions about the firms' success on the market, the values of means superior to 3 (with 5 being an upper limit) indicated that the majority of interviewed managers had considered their firms to be in the "success zone", regardless of being innovative or not,

- in all but one of analysed cases, the innovative small companies evaluated their success in least favourable terms, and the innovative medium-sized companies - in the most favourable terms.

Our findings have important implications for the innovations-promoting policies in Poland. If innovations do not seem to improve the perception of market success in the case of small enterprises, should they be encouraged to innovate by persuasion, fiscal incentives or subsidies? Maybe imitation or subcontracting could be considered as a better strategy for those companies?

There is, however, a possibility of psychological mechanism leading to such results. It should be investigated if the mere fact of working on innovative solutions leads to higher expectation of market success in the minds of managers. Therefore, if the success is "moderate", this may create frustration instead of satisfaction. This situation should be analyzed in future research with the help of success measures based on financial indicators.

The situation is clear in medium-sized enterprises: innovation leads to better evaluation of firms' success on the market and innovation-promoting policies seem to be easier to justify in this case. This finding should be validated in further research on larger samples. 


\section{CONCLUSION}

The main novelty of the presented research is the indication of the difference in managerial success perception between small and medium Polish INVs.

Obtained results lead to the conclusion that the hypothesis $\mathrm{H} 1$ has been partially confirmed: the medium-sized Polish INVs were more innovative than the small ones (the difference has not been significant in the second sample except for innovations in distribution).

As far as hypothesis $\mathrm{H} 2$ is concerned, there was no consistent relationship between innovativeness and the perceived success of Polish INVs on the market. Analysis of variance revealed the existence of repeated pattern of significant and not significant interactions.

This may be attributed to the fact, that bigger enterprises are better prepared to manage sophisticated innovation processes and to take advantage of new product introduction to the market.

Therefore, the most appropriate conclusion from these findings is that relationship between innovativeness and success on the market of Polish INVs is complex and should be subject to further research based on larger and more diversified samples and data collected over a longer time horizon with repeated measures for the same companies.

\section{REFERENCES}

Baranowska-Prokop, E., \& Sikora, T. (2014). Relationship Between Competitive Strategies and the Success Perception of Polish Born Globals. International Journal of Management and Economics, 43(1), 94-113.

Baranowska-Prokop, E., \& Sikora, T. (2016). Postrzeganie innowacyjności oraz jej związku z sukcesem firmy przez kadrę menedżerską polskich przedsiębiorstw wcześnie umiędzynarodowionych. Marketing i Rynek, (8), 25-31.

Church, N. C., \& Lewis, V. L. (1983). The Five Stages of Small Business Growth. Harvard Business Review, May-June.

Coviello, N. E. (2006). The network dynamics of international new ventures. Journal of international Business studies, 37(5), 713-731.

Danik, L., \& Kowalik, I. (2013). The studies on born global companies-a review of research methods. Journal of Economics \& Management, (13), 9-26.

Danik, L., \& Kowalik, I. (2015). Success factors and development barriers perceived by the Polish born global companies. Empirical study results. Journal of East European Management Studies, 360-390.

Duliniec, E. (2011). Koncepcje przedsiębiorstw wcześnie umiędzynarodowionych. Rozważania terminologiczne. Gospodarka Narodowa, 1, 63-80.

Galbraith, J. K. (1952). American Capitalism: The Concept of Countervailing Power. Boston: Houghton Mifflin.

Global Innovation Index. (2016). Retrieved 22.02.2017 from https://www.globalinnovationindex.org/gii-2016-report.

Gorynia, M. (2007). Strategie zagranicznej ekspansji przedsiębiorstw. Warszawa: PWE.

GUS. (2015). Drialalność innowacyjna przedsiębiorstw w latach 2012-2014. Informacje i Opracowania Statystyczne, Warszawa.

Jasiński, A. H. (2014). Innowacyjnosí w gospodarce polskiej. Modele, bariery, instrumenty wsparcia. Wydawnictwo Naukowe Wydziału Zarządzania Uniwersytetu Warszawskiego, Warszawa.

Kowalik, I., \& Baranowska-Prokop, E. (2013). Determinanty powstawania i motywy ekspansji polskich przedsiębiorstw wcześnie umiędzynarodowionych. Gospodarka Narodowa, 4(260), 41-64.

Macdonald, R. (1965). Schumpeter and Max Weber--central visions and social theories. The quarterly journal of economics, 373-396.

McDougall, P. P., \& Oviatt, B. M. (2000). International entrepreneurship: the intersection of two research paths. Academy of management Journal, 43(5), 902-906.

McDougall, P. P., Oviatt, B. M., \& Shrader, R. C. (2003). A comparison of international and domestic new ventures. Journal of international entrepreneurship, 1(1), 59-82. 
Mortensen, P. S., \& Bloch, C. W. (2005). Oslo Manual-Guidelines for Collecting and Interpreting Innovation Data: Proposed Guidelines for Collecting and Interpreting Innovation Data. Organisation for Economic Cooporation and Development, OECD.

Przybylska, K. (2010). Born global-nowa generacja małych polskich przedsiębiorstw. Gospodarka Narodowa, 7(8), 63-84. Przybylska, K. (2013). Born Global - nowa generacja malych præedsiębiorstw. Uniwersytet Ekonomiczny w Krakowie, Kraków. Raport PARP. (2015). Innowacyjna przedsiębiorczosí w Polsce. Odkryty i ukryty potencjat polskiej innowacyjności. Warszawa. Rennie, M. W. (1993). Born global. The McKinsey Quarterly, (4), 45-53.

Schumpeter, J. A. (1982). The Theory of Economic Development: An Inquiry into Profits, Capital, Credit, Interest, and the Business Cycle (1912/1934). Transaction Publishers.-1982.-January, 1, 244.

Servais, P., \& Rasmussen, E. S. (2000). Different types of international new ventures. Paper presented at the Annual Meeting of the Academy of International Business. Phoenix.

Zijdemans, E., \& Tanev, S. (2014). Conceptualizing innovation in born-global firms. Technology Innovation Management Review, 4(9), 6-10. 